\title{
ASSOCIATIONS BETWEEN SNPS IN THE GENES ENCODING UROKINASE SYSTEM PROTEINS AND THE RISK OF PLACENTAL INSUFFICIENCY
}

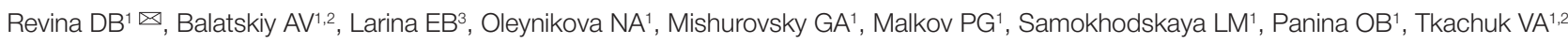

${ }^{1}$ Lomonosov Moscow State University, Moscow, Russia

${ }^{2}$ National Medical Research Center of Cardiology, Moscow, Russia

${ }^{3}$ Lapino Clinical Hospital "Mother and Child", Moscow, Russia

Placental insufficiency (PI) and its complications are multifactorial conditions that cause perinatal morbidity and mortality. Since the urokinase system is involved in placentation, it should have a role in PI pathogenesis. The aim of this work was to study the associations between single nucleotide polymorphisms (SNPs) of genes coding for protein components of the urokinase system and PI, as well as investigate their effect on the expression of these proteins in the placenta and placental structure. We examined 114 women with uncomplicated pregnancy and delivery, 48 female patients with pre-eclampsia and/or intrauterine growth restriction (IUGR), and 95 newborns, (pre-eclampsia and/or IUGR: $n=60$; uncomplicated pregnancy and delivery: $n=35$ ). Maternal and fetal DNAs were genotyped using real-time PCR. Placenta fragments were subjected to morphometry and immunohistochemistry. We discovered the associations between PI and the maternal C allele of rs4065 (PI group: CC-CT 64.1\%, Tा 35.9\%; controls: CC-CT 25.6\%, Tा 74.49\%; OR (95\%Cl): 6.83 (2.63-17.79)), the maternal A allele of rs2302524 (GG-GA 20.5\%, AA 79.5\% vs. GG-GA 48.1\%, AA 51.9\%, OR (95\%Cl): 0.27 (0.1-0.71)), the fetal C allele of rs4065 (CC-CT 76.4 \%, TT $23.6 \%$ vs. CC-CT $69.6 \%$, Tा 30.4\%, OR (95\%Cl): 1.37 (0.45-4.17)), and the fetal C allele of rs344781 (TT-TC 69.1\%, CC 30.9\% vs. TT-TC 95.7\%, CC 4.3\%, OR (95\% Cl): 5.02 (1.07-23.6)). The multivariate analysis confirmed the significance of the fetal rs4065 genotype. In patients with PI, uPA expression was lower (ME (95\%Cl): 116.45 (100.5; 128.74 ) vs. 126.09 (113.76; 139.19); $p$ < 0.05). No associations were established between SNPs and protein expression. The degree of vascularization depended on the maternal rs4065 genotype (the stroma-to-vessel ratio for the CC genotype was $0.17(0.15 ; 0.19)$; for the CT genotype, $0.18(0.15 ; 0.21)$ and for the $\Pi$ genotype, $0.23(0.2 ; 0.27) ; p<0.05)$. We conclude that high placental uPA and the presence of the fetal $T \mathrm{r}$ rs 4065 genotype are protective against the risk of PI.

Keywords: pre-eclampsia, intrauterine growth restriction, placental insufficiency, urokinase-type plasminogen activator, urokinase-type plasminogen activator receptor, single nucleotide polymorphism, angiogenesis

Funding: this study was conducted under the state assignment for Lomonosov MSU using the equipment acquired as part of the Scientific Development Program of Lomonosov MSU.

Acknowledgement: the authors thank Mamedov NN, PhD Med, an Assistant Professor at the Department of Obstetrics and Gynecology (Faculty of Fundamental Medicine, Lomonosov MSU) for his help in creating the collection of biosamples (umbilical cord and placenta fragments, blood samples).

Author contribution: Revina DB, Balatskiy AV, Larina EB, Samokhodskaya LM, Panina OB, Tkachuk VA — study design; Revina DB, Balatskiy AV, Larina EB, Oleynikova NA, Mishurovsky GA — collection and processing of biosamples and clinical datal; Revina DB, Balatskiy AV, Mishurovsky GA — statistical analysis; Revina DB, Balatskiy AV — interpretation of the results; Revina DB, Balatskiy AV, Oleynikova NA, Mishurovsky GA — manuscript preparation; Malkov PG, Samokhodskaya LM, Panina OB, Tkachuk VA — manuscript revision; Revina DB and Balatskiy AV equally contributed to the study.

Compliance with ethical standards: the study was approved by the Ethics Committee of Lomonosov MSU (Protocol 4 dated June 4 2018). All patients gave informed consent to participate.

$\triangle$ Correspondence should be addressed: Daria B. Revina

Lomonosovsky prospect, 27, k.1, Moscow, 119192; lozinskaya.daria@gmail.com

Received: 31.10.2019 Accepted: 18.11.2019 Published online: 07.12.2019

DOI: $10.24075 /$ brsmu.2019.076

\section{АССОЦИАЦИЯ SNP ГЕНОВ БЕЛКОВ УРОКИНАЗНОЙ СИСТЕМЫ С РАЗВИТИЕМ ПЛАЦЕНТАРНОЙ НЕДОСТАТОЧНОСТИ}

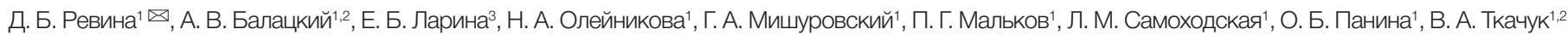

${ }^{1}$ Московский государственный университет имени М. В. Ломоносова, Москва, Россия

2 Национальный медицинский исследоваельский центр кардиологии, Москва, Россия

${ }^{3}$ Клинический госпиталь Лапино «Мать и дитя», Москва, Россия

Плацентарная недостаточность (ПН) и ее осложнения - многофакторные заболевания, ведущие к перинатальной заболеваемости и смертности. Урокиназная система задействована в формировании плаценты и может быть рассмотрена как участник патогенеза ПН. Целью работы было исследовать ассоциацию однонуклеотидных полиморфизмов (SNP) генов белков урокиназной системы с развитием ПН, их влияние на экспрессию соответствующих белков в плаценте и ее строение. Обследованы 114 женщин с физиологическим течением беременности и родов и 48 пациенток с преэклампсией и/или задержкой роста плода (ЗРП), 95 новорожденных детей (беременность с преэклампсией и/или ЗРП - 60, физиологическое течение беременности и родов - 35). Проведено генотипирование при помощи ПЦР в реальном времени, морфометрическое и иммуногистохимическое исследования фрагментов плацент. Выявлены ассоциации между развитием ПН и наличием у матери - аллеля C rs4065 (в группе ПН - CC-CT 64,1\%, ПТ 35,9\%, В контрольной группе - CC-СТ 25,6\%, Т 74,49\%, ОШ (95\% ДИ) - 6,83 (2,63-17,79)), аллеля A rs2302524 (GG-GA 20,5\%, AA 79,5\% против GG-GA 48,1\%, AA 51,9\%, ОШ (95\% ДИ) - 0,27 (0,1-0,71)), у плода — аллеля C rs4065 (CС-СТ 76,4 \%, ТТ 23,6\% против CС-СТ 69,6\%, Тт 30,4\%, ОШ (95\% ДИ) - 1,37 (0,45-4,17)), аллеля C rs344781 (ТТ-ТС 69,1\%, CС 30,9\% против ТТ-ТС 95,7\%, СС 4,3\%, ОШ (95\% ДИ) - 5,02 (1,07-23,6)). Многосакторный анализ подтвердил значимость генотипа плода по rs4065. Экспрессия uРА была ниже при ПН (медиана (95\% ДИ) - 116,45 (100,5; 128,74) против 126,09 (113,76; $139,19) ; p<0,05)$. Ассоциации SNP с экспрессией белков выявлено не было. Васкуляризация зависела от генотипа матери по rs4065 (стромальнососудистое соотношение при генотипе СС - 0,17 (0,15; 0,19), СТ - 0,18 (0,15; 0,21), ТТ - 0,23 (0,2; 0,27); p < 0,05). Таким образом, высокий уровень uPA в плаценте и наличие генотипа rs4065 ПТ у плода носят протективный характер в отношении развития ПН.

Ключевые слова: преэклампсия, задержка роста плода, плацентарная недостаточность, активатор плазминогена урокиназного типа, рецептор активатора плазминогена урокиназного типа, однонуклеотидный полиморфизм, ангиогенез

Финансирование: исследование выполнено в рамках государственного задания МГУ имени М. В. Ломоносова и с использованием оборудования, приобретенного по программе научного развития МГУ имени М. В. Ломоносова.

Благодарности: ассистенту кафедры акушерства и гинекологии факультета фундаментальной медицины МГУ имени Ломоносова, к. м. н. Николаю Назимовичу Мамедову за помощь в создании коллекции биоматериалов (фрагментов последов, образцов крови).

Информация о вкладе авторов: Д. Б. Ревина, А. В. Балацкий, Е. Б. Ларина, Л. М. Самоходская, О. Б. Панина и В. А. Ткачук - дизайн исследования; Д. Б. Ревина, А. В. Балацкий, Е. Б. Ларина, Н. А. Олейникова, Г. А. Мишуровский - сбор и обработка биоматериала, клинических данных Д. Б. Ревина, А. В. Балацкий, Г. А. Мишуровский - статанализ; Д. Б. Ревина, А. В. Балацкий - интерпритация результатов; Д. Б. Ревина, А. В. Балацкий, Г. А. Мишуровский, Н. А. Олейникова - написание рукописи; П. Г. Мальков. Л. М. Самоходская, О. Б. Панина, В. А. Ткачук - редактирование рукописи. Вклады Д. Б. Ревиной и А. В. Балацкого равноценны.

Соблюдение этических стандартов: исследование одобрено этическим комитетом Медицинского научно-образовательного центра МГУ имени М. В. Ломоносова (протокол № 4 от 4 июня 2018 г.). Все пациенты подписали добровольное информированное согласие на включение в исследование.

$\bowtie$ Для корреспонденции: Дарья Борисовна Ревина

Ломоносовский проспект, д. 27, корп. 1, г. Москва, 119192; lozinskaya.daria@gmail.com

Статья получена: 31.10.2019 Статья принята к печати: 18.11.2019 Опубликована онлайн: 07.12.2019

DOI: $10.24075 /$ vrgmu.2019.076 
Placental insufficiency $(\mathrm{PI})$ and the ensuing pregnancy complications, including intrauterine growth restriction (IUGR) and pre-eclampsia, are clinical manifestations of impaired placental perfusion. The mechanisms implicated in PI involve abnormal placental angiogenesis and villous maldevelopment caused by: 1) insufficient trophoblast invasion; 2) incomplete remodeling of spiral arteries; 3 ) imbalance between pro- and antiangiogenic factors; 4) maternal coagulation defects [1]. Therefore, research into PI etiology should be focused on the potential role of multifunctional regulatory systems, including the urokinase system, as contributors to the defects described above. The urokinase system consists of the urokinase-type plasminogen activator (UPA), its main substrate (plasminogen), plasminogen activator inhibitors (PAl-1, PAI-2), and the UPA receptor (UPAR); the latter regulates and improves the efficacy of urokinase-mediated proteolysis by binding to uPA [2]. The urokinase system can trigger a variety of signaling cascades and thereby transform the cellular environment through proteolysis of the extracellular matrix, as well as induce cell migration and proliferation in response to such transformations [3].

Almost all components of the urokinase system have genetic polymorphisms that affect UPA activity or the level of its expression. Today, there is sufficient evidence confirming the role of some of those genetic variants in promoting pregnancy complications. So far, associations between such polymorphisms and PI have been best studied for PAI-1. For example, the indel mutation in the SERPINE1 promoter (-675 $5 \mathrm{G} / 4 \mathrm{G}$ ) has been reliably linked to early pregnancy loss/preeclampsia [4, 5].

Polymorphisms of the urokinase and urokinase receptor genes are less studied. In this article, we investigate possible associations between PI and 4 SNPs: 2 of the PLAU gene (rs4065, rs2227564) and another 2 of the PLAUR gene (rs344781, rs2302524). PLAU rs4065 C/T $3^{\prime}-U T R$ is a C/T substitution in the noncoding gene region resulting in enhanced mRNA stability and hence aberrant uPA levels [6]. PLAU Pro141Leu (rs2227564) results in the increased hydrophobicity of the kringle domain, which reduces UPA affinity to fibrin and possibly the components of the extracellular matrix [7]. Although the role of the urokinase kringle domain is not fully clear, this polymorphism can alter urokinase activity. PLAUR rs2302524 (A659G) is another missense mutation that presumably affects the activity of the urokinase system [8]. PLAUR rs344781 affects the activity of the PLAUR promoter; the $\mathrm{T}$ allele enhances transcription [9]. Considering the significance of assessing both maternal and fetal components of the mother-placenta-fetus system, we analyzed the genotypes of the mother and the fetus. Genotyping data were compared to the results of a histopathological examination of placental specimens so as to determine the effect of gene polymorphisms on placental tissue morphology and the expression of urokinase system proteins. The aim of this work was to study the associations between PI and SNPs in the genes coding for the components of the UPA-uPAR-system, as well as their effects on the intensity of protein expression in placental tissue and placental morphology.

\section{METHODS}

The study was conducted at the Medical Research and Educational Center of Lomonosov Moscow State University in 2018. Samples of venous blood, placental tissue and umbilical cords, as well as clinical data, were obtained from the Center's Biobank. Originally, the samples had been collected from
162 female patients aged 20 to 49 years and 95 newborns immediately after delivery.

The control group consisted of 114 healthy women with uncomplicated pregnancy and delivery. The PI group included 48 patients with early pre-eclampsia ( $<34$ weeks into gestation) and/or early grade II-III IUGR (< 32 gestational weeks). IUGR was diagnosed based on a biometric lag of 2 weeks; the actual gestational age was inferred from the first day of the last menstrual period and from the findings of the early ultrasound scan. Pre-eclampsia was defined as elevated systolic $\mathrm{BP} \geq 140 \mathrm{mmHg}$ and diastolic $\mathrm{BP} \geq 90 \mathrm{mmHg}$ on at least two occasions after week 20 into gestation in the presence of at least one of the following signs: proteinuria $\geq 300 \mathrm{mg} / \mathrm{day}$, renal failure (hypercreatininemia $\geq 90 \mu \mathrm{mol} / \mathrm{L}$ ), liver dysfunction (ALT or AST > $40 \mathrm{IU} / \mathrm{L}$ ), impaired blood flow in the motherplacenta-fetus system on the Doppler scan, thrombocytopenia $<150,000 / \mu \mathrm{L}$, and neurological symptoms. The exclusion criteria were as follows: multifetal pregnancy, Rh-sensitization, gestational diabetes mellitus, severe extragenital pathology, drug abuse, smoking, fetal abnormalities or genetic disorders. All pregnancies were spontaneous. In order to exclude "small for gestational age" fetuses from the study, a Doppler scan of the umbilical artery was performed. Women with normal blood flow parameters were excluded.

Umbilical cord samples were collected from 60 newborns in the PI group (pregnancies complicated by pre-eclampsia and/ or IUGR) and 35 newborns in the control group (uncomplicated pregnancies and delivery). For the analysis, we selected umbilical cord fragments located $8-10 \mathrm{~cm}$ away from the placenta. The samples were fixed in 10\% formalin or frozen at $-80^{\circ} \mathrm{C}$. In 53 cases ( 25 patients with $\mathrm{PI}$ and 28 controls), we collected samples of maternal blood, umbilical cord fragments and placental tissue. For each mother-newborn pair, 3 fragments of seemingly healthy tissue sized $1 \times 0.5 \times 0.5 \mathrm{~cm}$ were collected from the peripheral, paracentral and central areas of the placenta; the fragments were fixed in 10\% buffered formalin for $12 \mathrm{~h}$; then the samples were dehydrated and embedded in paraffin. All placenta donors in the PI group gave birth by Caesarian section at $>28$ weeks gestation ( 2 patients before gestational week 34; 6 patients after week 34); in the control group, the babies were delivered at term.

\section{Genotyping}

DNA was isolated from $\mathrm{K}_{2}$ EDTA-containing peripheral maternal blood using a QIAmp DNA Blood Mini Kit and from umbilical cord fragments using a DNeasy Blood and Tissue Kit (QIAGEN; Germany) following the manufacturer's protocol. (the minimum sample weight of $25 \mathrm{mg}$ and prolonged overnight lysis).

PLAU C/T 3'-UTR (rs4065) and PLAUR T(-516)C (rs344781) polymorphisms were detected by real-time PCR. Amplification was performed in a RotorGene $Q$ thermocycler (QIAGEN; Germany). Allele-specific hydrolyzed probes were used. The following primers and probes were used: rs4065_F: 5'-TGGTTGTCATIITTGCAGTAGAGTC-3'; rs4065_R: 5'-GGCCTATGCCTGAGGGTAAAG-3'; rs4065_prC:FAM-5'-AAGCTATTGTCGTTCGCCCTGGTGG-3'-BHQ1; rs4065_prT: HEX-5'-AAGCTATTGTCGTTCACCCTGGTGGG3'-BHQ1;

rs344781_F: 5'-ATCCTGAAATATGCATCTCTTAAACACT-3'; rs344781_R: 5'-TTAACATTTACCAAGGACCTACTTCG-3'; rs344781_prC:FAM-5'-CACAGCGGGAAGCAAAGCAAGGGT3'-BHQ1:

rs344781_prT: HEX-5'-CACAGCAGGAAGCAAAGCAAGGGT3'-BHQ1). 
PLAU C/T 7240 (rs2227564), PLAUR A659G (rs2302524) and SERPINE1 -675 5G/4G polymorphisms were detected by real-time PCR using commercial kits for SNP detection (DNATechnology; Russia).

\section{Morphometry and immunohistochemistry}

Four- $\mu \mathrm{m}$ thick sections were prepared from paraffin blocks and mounted on Polysine Slides (Menzel GmbH \& Co KG; Germany). Dewaxing, rehydrating and epitope retrieval were performed using Dewax and HIER BufferM (pH 8.0) (Thermo; UK) at $95-98{ }^{\circ} \mathrm{C}$ for 20 min in the pre-treatment PT-Module (Thermo; UK). Immunohistochemistry reactions were carried out in a Thermo Scientific LabVision Autostainer 480S (Thermo; UK). The sections were incubated with $1: 150$ monoclonal rabbit anti-uPA antibodies (ab133563) and 1: 100 polyclonal rabbit anti-uPAR antibodies (ab103791) (Abcam; UK) for $30 \mathrm{~min}$. A chromogenic (DAB) Ultra Vision Quanto Detection System (Thermo; UK) was used to detect staining. Then, the sections were treated with hematoxylin (1-3 min) and covered with a cover-glass. The slides were examined under a Leica DM 1000 microscope equipped with an HI PLAN 40×/0.65 $\infty / 0.17 / 0 F N 25$ lens and a digital high-resolution camera Leica DMC 2900; the images were processed in Leica Application Suite 8.0 (Leica; Germany). A total of 1,060 microphotographs were taken: 530 for UPAR-treated and 530 for UPA-treated slides.

\section{Image processing}

On each image, an area of $7 \times 7$ pixels was selected in the background outside the specimen; this area was assigned an average color value of all the pixels it contained. This average value was used to white-balance the image, so that the corrected color would be white. As a result, the background on all images appeared very close to white and all microphotographs did not differ in color tones. After color normalization, large clusters of red blood cells and artifacts were manually selected and removed on each photograph. All images were resized to $1024 \times 768$ pixels.

\section{Measured parameters}

Using ImageJ, v1.51s (National Institutes of Health; USA), we calculated the villi surface area $\left(\mathrm{mm}^{2}\right)$ and the area occupied by the intervillous space $\left(\mathrm{mm}^{2}\right)$ for each image. To estimate the vessel surface area (\% of the villi surface area), the stroma-tovessel ratio and the intensity of UPA/UPAR expression in the villi, blood vessels were highlighted manually. The stroma-tovessel ratio was determined by the formula: vessel surface area / (villi surface area - vessel surface area). All parameters were calculated as a geometric mean from 10 processed images per section.

\section{Measurement of marker expression intensity}

To estimate the intensity of UPA and UPAR expression, the ImageJ color threshold function was applied to the areas representing villi on the images. The following parameters were used: hue [0;37], saturation [46;255] and brightness [62;251], as they allow detecting a vast variety of brown tones. The selected areas were converted into black and white to evaluate pixel color intensity. Purely black pixels were assigned the value of 255 , whereas purely white pixels, 0 . All pixels outside the villi or those outside the specified color range were assigned a 0 value. The mean color value was calculated for each image based on non-white pixels (color $\neq 0$ ). Expression intensity was calculated by the formula: ,

$$
\text { INT }=\frac{\sum_{c=0}^{255} C \times N_{c}}{V_{i} \times 1024 \times 768},
$$

where INT is intensity; $c$ is the mean color value for non-white pixels; $N$ is the number of pixels with the specific $c ; V$ is the area of the image occupied by the villi expressed in the range from 0 to 1 . The yielded values can be interpreted as uPA UPAR expression intensity in the range from 0 (no expression) to 255 (maximum expression) providing that staining of the villi is uniform.

\section{Statistical analysis}

Statistical analysis was conducted in RStudio v1.1.453 and the SNP Stats web tool [10] developed for the analysis of genetic polymorphism data. The Akaike information criterion was used to choose the type of inheritance model (codominant, dominant, recessive, overdominant, or log-additive). We selected models with the lowest AIC indicating better goodness of fit in the presence of fewer parameters. Continuous variables were tested for normality using the Shapiro-Wilk test. Differences between the groups were assessed using Student's $t$-test, one-way ANOVA for parametric data, the Wilcoxon rank-sum test, or the Tukey test for nonparametric data depending on the number of groups, the Kruskal-Wallis test. Categorical variables were assessed using the $\chi^{2}$ test. Odds ratios for the risk of $\mathrm{PI}$ were also calculated. Univariate binary logistic regression models were used to construct $95 \% \mathrm{Cl}$ and estimate OR pointwise. Statistical weight and significance of individual genotypes were analyzed using logistic regression. Differences were considered significant at $p<0.05$.

\section{RESULTS}

Table 1 shows frequencies of maternal and fetal SNPs significantly associated with the risk of PI (corrected to maternal age). Associations have been established between $\mathrm{PI}$ and the following alleles: the maternal C allele PLAU rs4065, the maternal A allele PLAUR rs2302524, the fetal C allele PLAU rs4065, and the fetal C allele PLAUR rs344781. To study the effects of both maternal and fetal genotypes, we built a model in which PI was the dependent variable and maternal and fetal genotypes were predictors (the presence of 2 mutant alleles scored 2 points, heterozygous variants scored 1 point, and the presence of 2 referent alleles scored 0). Then, we estimated the statistical significance of the predictors, their weight and effect (positive or negative). Characteristics of the model are provided in Table 2; a statistically significant effect was demonstrated for the fetal PLAU rs4065 polymorphism: the C to T substitution was protective against PI, i.e. reduced its probability; $\Pi$ was the most prognostically favorable genotype.

In the control group samples, villous tree architecture was normal, dominated by terminal villi with sinusoidally dilated capillaries and showing an intimate contact between the trophoblastic surface and the vascular wall underneath. In the PI group, a variety of histopathologic phenomena were observed. In some cases, nonbranching angiogenesis prevailed presenting as the lack of terminal villi, small villous diameter and the absence of syncytial knotting. In 16 cases, an excessive compensatory placental response was observed, including angiomatosis of the villi, extensive syncytial knotting in the aggregated terminal villi and the narrowing of the intervillous space. These findings were fortified by the estimates of 
the villi surface area and the intervillous space (Table 3). No differences were found between the PI and control groups in the vessel surface area and the stroma-to-vessel ratio (Table 3), which may be explained by the morphological heterogeneity observed in patients with preeclampsia and IUGR, as well as by the difference in gestational age at delivery.

The data yielded by genotyping of maternal and fetal specimens were compared to the results of the microscopic examination of the placenta (morphometric parameters and the immunohistochemical expression of UPA and UPAR). The intensity of UPA/UPAR expression in syncytiotrophoblasts exceeded that in the stromal cells and the endothelium of villous vessels (Fig. $1 \mathrm{~A}-\mathrm{D}$ ). The intensity of uPA expression was reliably lower in the placental tissue of patients with $\mathrm{PI}$ $(p=0.033$ ) (Table 3; Fig. 1A-B); no difference in uPAR expression was observed between the groups (Table 3; Fig. 1C-D).

Table 1. Genotype frequencies for urokinase system SNPs associated with the risk of PI

\begin{tabular}{|c|c|c|c|c|c|c|c|}
\hline & Inheritance model & Genotype & $\mathrm{PI}, \%(n)$ & Control \% (n) & OR $(\mathrm{Cl} 95 \%)^{\star}$ & $p$ & $\mathrm{AlC}$ \\
\hline \multicolumn{8}{|c|}{ maternal SNP } \\
\hline \multirow{10}{*}{ PLAU rs4065 } & \multirow{3}{*}{ Codominant } & $\mathrm{C} / \mathrm{C}$ & $23.1(9)$ & $3.8(3)$ & $12.90(2.68-51.68)$ & \multirow{3}{*}{0.0001} & \multirow{3}{*}{120.9} \\
\hline & & $\mathrm{C} / \mathrm{T}$ & $41(16)$ & $21.8(17)$ & $5.46(1.94-15.37)$ & & \\
\hline & & $\mathrm{T} / \mathrm{T}$ & $35.9(14)$ & $74.4(58)$ & 1 & & \\
\hline & \multirow{2}{*}{ Dominant } & $\mathrm{C} / \mathrm{T}-\mathrm{C} / \mathrm{C}$ & $64.1(25)$ & $25.6(20)$ & $6.83(2.63-17.79)$ & \multirow{2}{*}{$<0.0001$} & \multirow{2}{*}{120.1} \\
\hline & & $\mathrm{T} / \mathrm{T}$ & $35.9(14)$ & $74.4(58)$ & 1 & & \\
\hline & \multirow{2}{*}{ Recessive } & $\mathrm{C} / \mathrm{C}$ & $23.1(9)$ & $3.8(3)$ & $6.97(1.58-30.68)$ & \multirow{2}{*}{0.006} & \multirow{2}{*}{130} \\
\hline & & $\mathrm{T} / \mathrm{T}-\mathrm{C} / \mathrm{T}$ & $76.9(30)$ & $96.2(75)$ & 1 & & \\
\hline & \multirow{2}{*}{ Overdominant } & $\mathrm{C} / \mathrm{C}-\mathrm{T} / \mathrm{T}$ & $59(23)$ & $78.2(61)$ & 1 & \multirow{2}{*}{0.01} & \multirow{2}{*}{131} \\
\hline & & $\mathrm{C} / \mathrm{T}$ & $41(16)$ & $21.8(17)$ & $3.46(1.33-9.03)$ & & \\
\hline & Additive & - & - & - & $4.14(2.02-8.51)$ & $<0.0001$ & 119.5 \\
\hline \multirow{10}{*}{ PLAUR rs2302524 } & \multirow{3}{*}{ Codominant } & $\mathrm{A} / \mathrm{A}$ & $79.5(31)$ & $51.9(42)$ & 1 & \multirow{3}{*}{0.02} & \multirow{3}{*}{133.7} \\
\hline & & $\mathrm{A} / \mathrm{G}$ & $15.4(6)$ & $38.3(31)$ & $0.27(0.09-0.77)$ & & \\
\hline & & $\mathrm{G} / \mathrm{G}$ & $5.1(2)$ & $9.9(8)$ & $0.30(0.05-0.68)$ & & \\
\hline & \multirow{2}{*}{ Dominant } & $\mathrm{A} / \mathrm{A}$ & $79.5(31)$ & $51.9(42)$ & 1 & \multirow{2}{*}{0.005} & \multirow{2}{*}{131.8} \\
\hline & & $\mathrm{A} / \mathrm{G}-\mathrm{G} / \mathrm{G}$ & $20.5(8)$ & 48.1 (39) & $0.27(0.1-0.71)$ & & \\
\hline & \multirow{2}{*}{ Recessive } & $\mathrm{A} / \mathrm{A}-\mathrm{A} / \mathrm{G}$ & $94.9(37)$ & $90.1(73)$ & 1 & \multirow{2}{*}{0.31} & \multirow{2}{*}{138.5} \\
\hline & & $\mathrm{G} / \mathrm{G}$ & $5.1(2)$ & $9.9(8)$ & $0.43(0.08-2.41)$ & & \\
\hline & Prordominont & $\mathrm{A} / \mathrm{A}-\mathrm{G} / \mathrm{G}$ & $84.6(33)$ & $61.7(50)$ & 1 & 0010 & 121 \\
\hline & 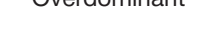 & $\mathrm{A} / \mathrm{G}$ & $15.4(6)$ & $38.3(31)$ & $0.31(0.11-0.87)$ & 0.010 & 104 \\
\hline & Additive & - & - & - & $0.39(0.18-0.85)$ & 0.01 & 132.9 \\
\hline & & & fetal S & & & & \\
\hline & & $\mathrm{C} / \mathrm{C}$ & $30.9(17)$ & $4.3(1)$ & $8.25(0.88-77.21)$ & & \\
\hline & Codominant & $\mathrm{C} / \mathrm{T}$ & $45.5(25)$ & $65.2(15)$ & $0.91(0.29-2.87)$ & 0.031 & 92.8 \\
\hline & & $\mathrm{T} / \mathrm{T}$ & $23.6(13)$ & $30.4(7)$ & 1 & & \\
\hline & Rominont & $\mathrm{C} / \mathrm{T}-\mathrm{C} / \mathrm{C}$ & $76.4(42)$ & $69.6(16)$ & $1.37(0.45-4.17)$ & 050 & 07. \\
\hline & 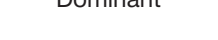 & $\mathrm{T} / \mathrm{T}$ & $23.6(13)$ & $30.4(7)$ & 1 & 0.00 & 91.4 \\
\hline ש & Dononging & $\mathrm{C} / \mathrm{C}$ & $30.9(17)$ & $4.3(1)$ & $8.82(1.09-71.67)$ & מחת ח & 00 \\
\hline & necessive & $\mathrm{T} / \mathrm{T}-\mathrm{C} / \mathrm{T}$ & $69.1(38)$ & $95.7(22)$ & 1 & 0.000 & 50.0 \\
\hline & & $\mathrm{C} / \mathrm{T}$ & $45.5(25)$ & $65.2(15)$ & $0.47(0.17-1.31)$ & & \\
\hline & Uveraominant & $\mathrm{C} / \mathrm{C}-\mathrm{T} / \mathrm{T}$ & $54.5(30)$ & $34.8(8)$ & 1 & 0.14 & 95.5 \\
\hline & Additive & - & - & - & $1.99(0.92-4.29)$ & 0.073 & 94.5 \\
\hline & & $\mathrm{T} / \mathrm{T}$ & $23.6(13)$ & $30.4(7)$ & 1 & & \\
\hline & Codominant & $\mathrm{T} / \mathrm{C}$ & $45.5(25)$ & $65.2(15)$ & $0.28(0.11-0.71)$ & 0.014 & 117.9 \\
\hline & & $\mathrm{C} / \mathrm{C}$ & $30.9(17)$ & $4.3(1)$ & $2.71(0.53-13.76)$ & & \\
\hline & Romingnt & $\mathrm{T} / \mathrm{T}$ & $23.6(13)$ & $30.4(7)$ & 1 & 0.098 & 131.4 \\
\hline PLAUR rs344781 & 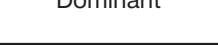 & $\mathrm{T} / \mathrm{C}-\mathrm{C} / \mathrm{C}$ & $76.4(42)$ & $69.6(16)$ & $0.49(0.21-1.16)$ & & \\
\hline & Donongivs & $\mathrm{T} / \mathrm{T}-\mathrm{T} / \mathrm{C}$ & $69.1(38)$ & $95.7(22)$ & 1 & 0.018 & 128.5 \\
\hline & Hecessive & $\mathrm{C} / \mathrm{C}$ & $30.9(17)$ & $4.3(1)$ & $5.02(1.07-23.6)$ & & \\
\hline & uprdomin & $\mathrm{C} / \mathrm{C}-\mathrm{T} / \mathrm{T}$ & $54.5(30)$ & $34.8(8)$ & 1 & $7 e-4$ & 122.7 \\
\hline & & $\mathrm{T} / \mathrm{C}$ & $45.5(25)$ & $65.2(15)$ & $0.22(0.09-0.54)$ & & \\
\hline & Additive & - & - & - & $1.00(0.57-1.77)$ & 0.99 & 134.1 \\
\hline
\end{tabular}

Note: * — OR (95\% Cl) adjusted for maternal age. 
No associations were established between the studied SNPs in PLAU and PLAUR and the intensity of protein expression in placental tissue.

The protective effect of the $\mathrm{C}$ to $\mathrm{T}$ substitution in maternal PLAU rs4065 was confirmed by its relationship with the degree of villous vascularization: the vessel surface area (\% of the villi surface area) and the stroma-to-vessel ratio varied depending on the genotype (Fig. 2). The maximum vasculature corresponded to the $\Pi$ genotype (Table 4).

\section{DISCUSSION}

The URA-UPAR system is multifunctional. It exerts fibrinolytic activity, participates in degrading the extracellular matrix, affects the bioavailability of growth factors, and regulates cell migration and proliferation. Once the embryo has been implanted, trophoblast cells start to express urokinase [11], and UPAR expression increases at the cell pole involved in trophoblast invasion; throughout the process, UPA activity is regulated by PAI-1,2. Thus, the urokinase system takes an active part in the modulated trophoblast invasion. Natural killers and macrophages are another source of UPA in the placenta. They ensure remodeling of spiral arteries in the endometrium at trophoblast-independent stages; by interacting with NK and macrophages, uPAR-positive smooth muscle cells and endothelial cells acquire their migration phenotype [12, 13]. The urokinase system (specifically, the cells expressing its protein components) "supervises" formation and degradation of fibrin-type fibrinoid [14]. Proteolysis of the extracellular matrix by serine proteases leads to the release of angiogenic factors from its scaffold, including vascular endothelial growth factor
(VEGF). The interaction between VEGF and its class 2 receptor results in the exposure of the proteolytic UPA-uPAR complex to integrins [15], confirming the role of the urokinase system as a mediator of angiogenic factors and an active participant of angiogenesis in the placenta.

In this study, we attempted to assess the risk of placentaassociated pregnancy complications based on the presence of SNPs in maternal and fetal genes. We were able to demonstrate that the TT genotype of PLAU rs4065 was associated with the lowest risk for $\mathrm{Pl}$. Considering that in the majority of cases the placental and the fetal genotypes are the same, the fetal $T$ allele should be regarded as more significant. Unfortunately, we could not prove that abnormal uPA levels in the placenta are determined by the SNPs in the corresponding gene, which might be explained by the small sample size. However, the association between the $\Pi$ genotype and the greater vessel surface area in the villi confirms the observed phenomenon.

Previously UPAR expression in chorionic villi was demonstrated to be higher in females with uncomplicated pregnancies than in those at risk of pregnancy loss [16]. The immunohistochemistry analysis conducted as part of our study revealed that UPAR levels in the placenta did not differ between healthy females and patients with placenta-related pregnancy complications. However, the groups did differ in terms of urokinase expression intensity.

There was no previous solid evidence of the direct effect of rs 4065 on the level of uPA expression. Our findings suggest that the $\Pi$ genotype stimulates cell migration and proliferation, is proangiogenic and reduces the risk of Pl. Our observation is confirmed by the fact that this polymorphism increases the risk of tumor growth and enhances tumor angiogenesis. There

Table 2. Parameters of the regression model showing the relationship between the risk of PI and SNPs in the genes encoding urokinase system proteins

\begin{tabular}{|c|c|c|c|c|}
\hline & Coefficients of factors & Standard error & $z$-score & $p$ \\
\hline Free coefficient & -0.6347 & 1.4248 & -0.445 & 0.656 \\
\hline \multicolumn{5}{|c|}{ Fetal SNP } \\
\hline PLAU rs2227564 & 4.0476 & 2.4788 & 1.778 & 0.075 \\
\hline SERPINE-1rs1799889 & 0.1157 & 1.2417 & 0.093 & 0.926 \\
\hline PLAU rs4065 & -3.3538 & 1.3791 & -2.432 & 0.015 \\
\hline PLAUR rs344781 & 2.7448 & 1.5893 & 1.727 & 0.084 \\
\hline PLAUR rs2302524 & 0.3755 & 1.4117 & 0.266 & 0.79 \\
\hline \multicolumn{5}{|c|}{ Maternal SNP } \\
\hline PLAU rs2227564 & -1.9485 & 1.3233 & -1.472 & 0.141 \\
\hline SERPINE-1rs1799889 & -2.276 & 1.387 & -1.641 & 0.101 \\
\hline PLAU rs4065 & 1.8566 & 0.985 & 1.885 & 0.059 \\
\hline PLAUR rs344781 & -0.7773 & 1.3769 & -0.564 & 0.572 \\
\hline PLAUR rs2302524 & 2.0156 & 1.3489 & 1.494 & 0.135 \\
\hline
\end{tabular}

Table 3. Morphological characteristics and immunohistochemical expression of UPA/UPAR in placental tissue

\begin{tabular}{|c|c|c|c|}
\hline & \multicolumn{2}{|c|}{ Median $(95 \% \mathrm{Cl})$} & \multirow[t]{2}{*}{$p$} \\
\hline & $\mathrm{PI}$ & Control & \\
\hline Villi surface area $\left(\mathrm{mm}^{2}\right)$ & $7.445(6.852 ; 7.863)$ & $6.464(6.213 ; 7.157)$ & 0.005 \\
\hline Intervillous space $\left(\mathrm{mm}^{2}\right)$ & $6.621(6.22 ; 7.17)$ & $7.611(6.887 ; 7.84)$ & 0.007 \\
\hline Vessel surface area (\% of villi surface area) & $19.55(16.45 ; 24.85)$ & $18.2(14.2 ; 22.6)$ & 0.326 \\
\hline Stroma-to-vessel ratio & $0.206(0.166 ; 0.26)$ & $0.178(0.147 ; 0.253)$ & 0.462 \\
\hline uPA expression & $116.449(100.496 ; 128.74)$ & $126.087(113.761 ; 139.191)$ & 0.033 \\
\hline uPAR expression & $117.59(96.24 ; 138.94)$ & $130.42(107.93 ; 152.91)$ & 0.351 \\
\hline
\end{tabular}


A

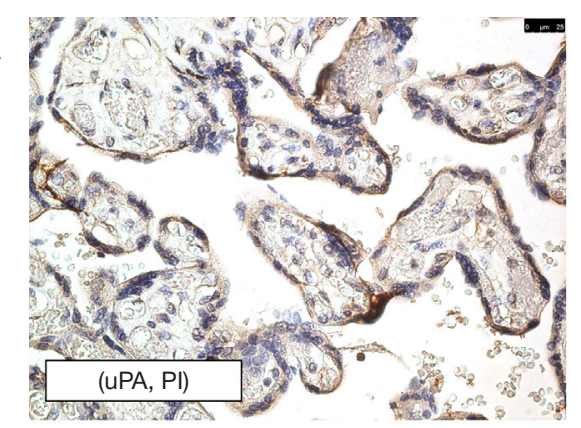

C
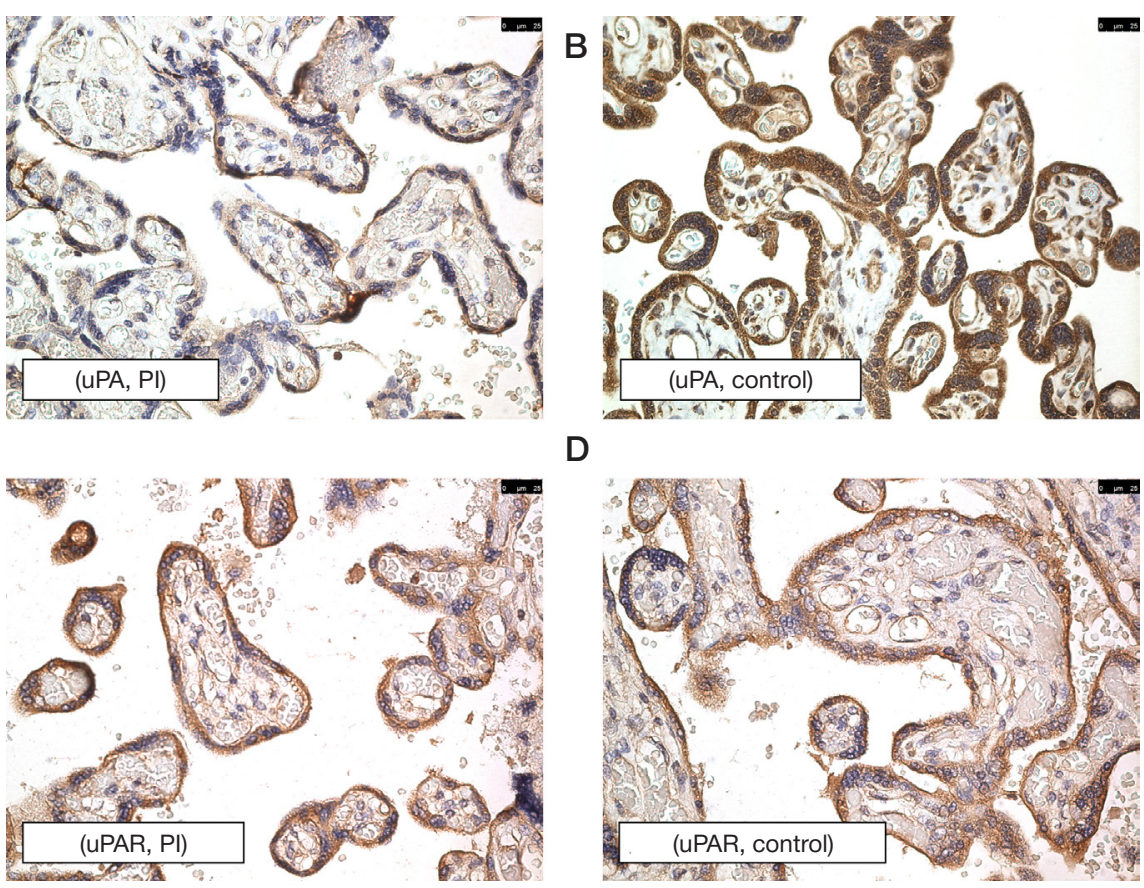

D

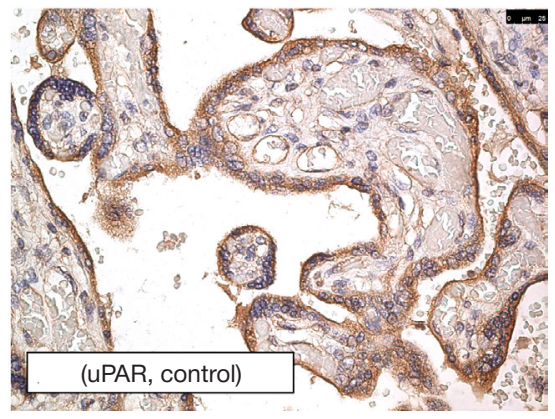

Fig. 1. Immunohistochemical expression of UPA (A, B) and UPAR (C, D) in the chorionic villi in the controls (A, C) and the PI group (B, D). Staining of syncytiotrophoblast cells with anti- UPA and anti- UPAR antibodies produces intense coloration in healthy tissue and samples of PI patients (A-D). Placental tissue of patients with PI (A) shows less intense coloration of ssyncytiotrophoblast cells after uPA staining in comparison with the control group (B). No difference was observed in immunohistochemical uPAR expression between the groups (C, D). Scale bar: $25 \mu \mathrm{m}$
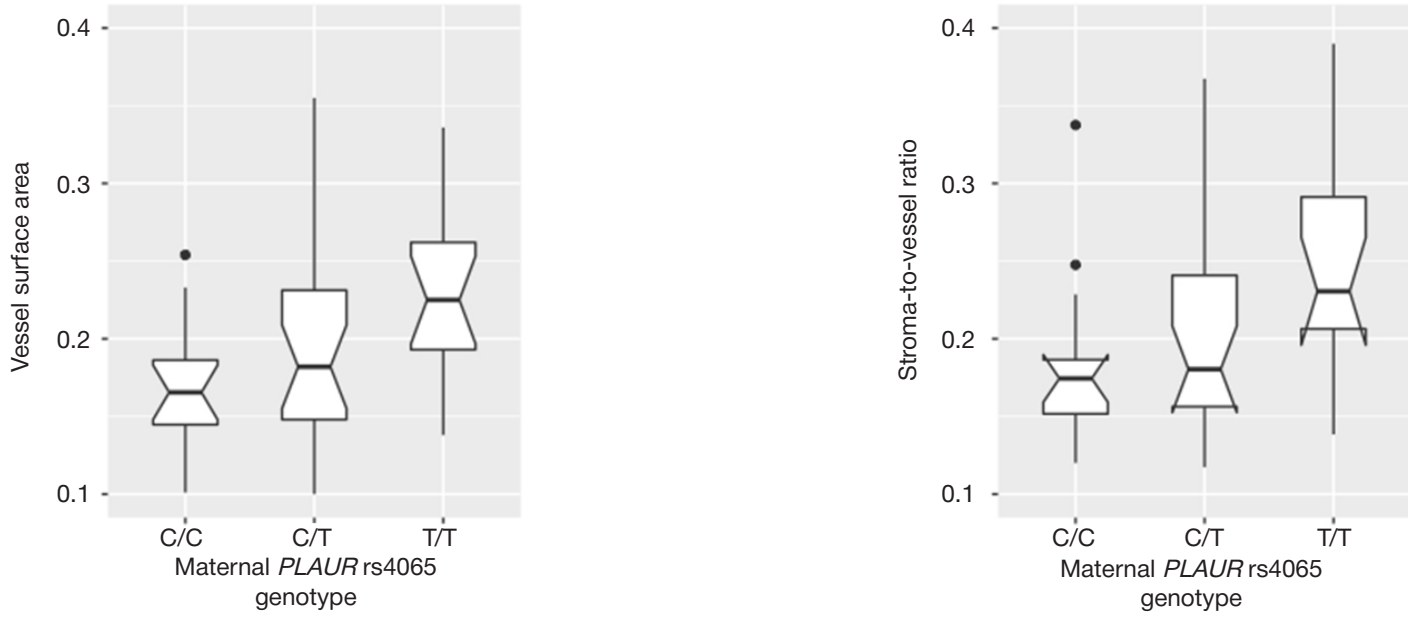

Fig. 2. The vessel surface area and the stroma-to-vessel ratio for different maternal PLAU rs 4065 genotypes. The ends of the box are Q1 and Q3; the vertical line inside the box is the median. The ends of the whiskers: Q1 minus 1.5 IQR; Q3 plus 1.5 IQR. Outliers are represented by dots. Confidence intervals are represented by notches

Table 4. The vessel surface area and the stroma-to-vessel ratio for different maternal PLAU rs4065 genotypes

\begin{tabular}{|c|c|c|c|c|c|c|}
\hline \multirow{2}{*}{ rs4065 genotype } & \multicolumn{3}{|c|}{ Vessel surface area, $\mathrm{mm}^{2}$} & \multicolumn{3}{|c|}{ Stroma-to-vessel ratio } \\
\hline & Median & $95 \% \mathrm{Cl}$ & $p^{\star \star}$ & Median & $95 \% \mathrm{Cl}$ & $p^{\star \star}$ \\
\hline $\mathrm{CC}$ & 0.1655 & {$[0.1461 ; 0.1849]$} & \multirow{3}{*}{0.0305} & 0.1715 & {$[0.1524 ; 0.1907]$} & \multirow{3}{*}{0.0265} \\
\hline CT & 0.182 & {$[0.1528 ; 0.2112]$} & & 0.1804 & {$[0.1485 ; 0.2123]$} & \\
\hline$\pi$ & 0.225 & {$[0.1969 ; 0.2531]$} & & 0.2306 & {$[0.1959 ; 0.2652]$} & \\
\hline
\end{tabular}

Note: ${ }^{\star *}$ - the Kruskal-Wallis test applied.

are reports of the significantly increased risk for cancer in the presence of the $T$ allele and the $T$ genotype [17-19]. At the same time, it is known that high uPA levels in some tumors predict a poor outcome [20]. Besides, the T allele of rs4065 has been linked to Quebec platelet disorder caused by excess fibrinolysis due to elevated uPA content in platelets [21].

\section{CONCLUSIONS}

High placental UPA and the fetal TT genotype (PLAU rs4065) are protective against the risk of $\mathrm{PI}$. We hope that our findings will expand the potential of noninvasive prenatal screening and predict PI by genotyping fetal DNA for rs4065 PLAU. 
1. Benirschke K, Burton GJ, Baergen RN. Pathology of the Human Placenta, 6th ed. Springer, 2012; p. 411.

2. Poettler M, Unseld M, Mihaly-Bison J, Uhrin P, Koban F. Binder BR, et al. The urokinase receptor (CD87) represents a central mediator of growth factor-induced endothelial cell migration. Thromb Haemost. 2012; 108 (8): 357-66.

3. Tkachuk VA, Plekhanova OS, Parfyonova YV. Regulation of arterial remodeling and angiogenesis by urokinase-type plasminogen activator. Can J Physiol Pharmacol. 2009; 87 (4): 231-51.

4. Khosravi F, Zarei S, Ahmadvand N, Akbarzadeh-Pasha Z, Savadi E, Zarnani A, et al. Association between plasminogen activator inhibitor 1 gene mutation and different subgroups of recurrent miscarriage and implantation failure. J Assist Reprod Genet. 2014; 31 (1): 121-4.

5. Zhao L, Bracken MB, DeWan AT, Chen S. Association between the SERPINE1 (PAl-1) 4G/5G insertion/deletion promoter polymorphism (rs1799889) and pre-eclampsia: A systematic review and meta-analysis. Molecular Human Reproduction. 2013; 19 (3): 136-43.

6. Tran H, Maurer F, Nagamine Y. Stabilization of urokinase and urokinase receptor mRNAs by HuR is linked to its cytoplasmic accumulation induced by activated mitogen-activated protein kinase-activated protein kinase 2. Mol Cell Biol. 2003; 23 (20): 7177-88.

7. Xu J, Li W, Bao X, Ding H, Chen J, Zhang W, et al. Association of putative functional variants in the PLAU gene and the PLAUR gene with myocardial infarction. Clin Sci (Lond). 2010; 119 (8): 353-9.

8. Yosrlimoto M, Youichi, Ushiyama Y, Sakaia M, Tamakia S, Hara H, et al. Characterization of single chain urokinase-type plasminogen activator with a novel amino-acid substitution in the kringle structure. Biochimica et Biophysica Acta (BBA)-Protein Structure and Molecular Enzymology. 1996; 1293 (1): 83-9.

9. Campbell DB, Li C, Sutcliffe JS, Persico AM, Levitt P. Genetic evidence implicating multiple genes in the met receptor tyrosine kinase pathway in autism spectrum disorder. Autism Res. 2008; 1 (3): 159-68.

10. Solé X, Guinó E, Valls J, Iniesta R, Moreno V. SNPStats: a web tool for the analysis of association studies. Bioinformatics. 2006; 22 (15): 1928-29.

11. Martínez-Hernández MG, Baiza-Gutman LA, Castillo-Trápala A,

\section{Литература}

1. Benirschke K, Burton GJ, Baergen RN. Pathology of the Human Placenta, 6th ed. Springer, 2012; p. 411.

2. Poettler M, Unseld M, Mihaly-Bison J, Uhrin P, Koban F. Binder BR, et al. The urokinase receptor (CD87) represents a central mediator of growth factor-induced endothelial cell migration. Thromb Haemost. 2012; 108 (8): 357-66.

3. Tkachuk VA, Plekhanova OS, Parfyonova YV. Regulation of arterial remodeling and angiogenesis by urokinase-type plasminogen activator. Can J Physiol Pharmacol. 2009; 87 (4): 231-51.

4. Khosravi F, Zarei S, Ahmadvand N, Akbarzadeh-Pasha Z, Savadi E, Zarnani $A$, et al. Association between plasminogen activator inhibitor 1 gene mutation and different subgroups of recurrent miscarriage and implantation failure. J Assist Reprod Genet. 2014; 31 (1): 121-4.

5. Zhao L, Bracken MB, DeWan AT, Chen S. Association between the SERPINE1 (PAI-1) 4G/5G insertion/deletion promoter polymorphism (rs1799889) and pre-eclampsia: A systematic review and meta-analysis. Molecular Human Reproduction. 2013; 19 (3): 136-43.

6. Tran H, Maurer F, Nagamine Y. Stabilization of urokinase and urokinase receptor mRNAs by HuR is linked to its cytoplasmic accumulation induced by activated mitogen-activated protein kinase-activated protein kinase 2. Mol Cell Biol. 2003; 23 (20): 7177-88

7. Xu J, Li W, Bao X, Ding H, Chen J, Zhang W, et al. Association
Armant DR. Regulation of proteinases during mouse periimplantation development: Urokinase-type plasminogen activator expression and cross talk with matrix metalloproteinase 9 . Reproduction. 2011; 141 (2): 227.

12. Lash GE, Otun HA, Innes BA, Percival K, Searle RF, Robson SC, et al. Regulation of extravillous trophoblast invasion by uterine natural killer cells is dependent on gestational age. Hum Reprod. 2010; 25 (5): 1137-45.

13. Naruse K, Lash GE, Bulmer JN, Innes BA, Otun HA, Searle RF, et al. The Urokinase Plasminogen Activator (UPA) System in Uterine Natural Killer Cells in the Placental Bed During Early Pregnancy. Placenta. 2009; 30 (5): 398-404.

14. Pierleoni C, Castellucci M, Kaufmann P, Lund LR, Schnack Nielsen B, Urokinase receptor is up-regulated in endothelial cells and macrophages associated with fibrinoid deposits in the human placenta. Placenta. 2003; 24 (6): 677-85

15. Breuss JM, Uhrin P. VEGF-initiated angiogenesis and the UPA uPAR system. Cell adhesion \& migration. 2012; 6 (6): 535-40.

16. Liu S, Zheng Q, Cui XY, Dai KX, Yang XS, Li FS, et al. Expression of UPAR in human trophoblast and its role in trophoblast invasion. Int J Clin Exp Pathol [Internet]. e-Century Publishing Corporation 2015; 8 (11): 14325-34. Available from: https://www.ncbi.nlm. nih.gov/pmc/articles/PMC4713534/.

17. Xu Z, Meng L-L, Lin J, Ling Y, Chen S, Lin N. Association between the polymorphisms of urokinase plasminogen activation system and cancer risk: a meta-analysis. Onco Targets Ther [Internet] Dove Medical Press. 2015; 9 (8): 2493-502. Available from: http://www.ncbi.nlm.nih.gov/pmc/articles/PMC4574847/.

18. Andreasen P, Kjøller L, Christensen L, Duffy MJ. The urokinasetype plasminogen activator system in cancer metastasis: a review. Int J Cancer. 1997; 72 (1): 1-22.

19. Duffy MJ, Maguire TM, McDermott EW, O'Higgins N. Urokinase plasminogen activator: a prognostic marker in multiple types of cancer. J Surg Oncol. 1999; 71 (2): 130-5.

20. Fuhrman B. The urokinase system in the pathogenesis of atherosclerosis. Atherosclerosis. Ireland; 2012 May; 222 (1): 8-14.

21. Diamandis $M$, Paterson AD, Rommens JM, Veljkovic DK, Blavignac J, Bulman DE, et al. Quebec platelet disorder is linked to the urokinase plasminogen activator gene (PLAU) and increases expression of the linked allele in megakaryocytes. Blood. 2009; $113(7): 1543-6$

of putative functional variants in the PLAU gene and the PLAUR gene with myocardial infarction. Clin Sci (Lond). 2010; 119 (8): 353-9.

8. Yosrlimoto M, Youichi, Ushiyama Y, Sakaia M, Tamakia S, Hara H, et al. Characterization of single chain urokinase-type plasminogen activator with a novel amino-acid substitution in the kringle structure. Biochimica et Biophysica Acta (BBA)-Protein Structure and Molecular Enzymology. 1996; 1293 (1): 83-9.

9. Campbell DB, Li C, Sutcliffe JS, Persico AM, Levitt P. Genetic evidence implicating multiple genes in the met receptor tyrosine kinase pathway in autism spectrum disorder. Autism Res. 2008; 1 (3): 159-68.

10. Solé X, Guinó E, Valls J, Iniesta R, Moreno V. SNPStats: a web tool for the analysis of association studies. Bioinformatics. 2006; 22 (15): 1928-29.

11. Martínez-Hernández MG, Baiza-Gutman LA, Castillo-Trápala A Armant DR. Regulation of proteinases during mouse periimplantation development: Urokinase-type plasminogen activator expression and cross talk with matrix metalloproteinase 9. Reproduction. 2011; 141 (2): 227.

12. Lash GE, Otun HA, Innes BA, Percival K, Searle RF, Robson SC, et al. Regulation of extravillous trophoblast invasion by uterine natural killer cells is dependent on gestational age. Hum Reprod. 2010; 25 (5): 1137-45.

13. Naruse K, Lash GE, Bulmer JN, Innes BA, Otun HA, Searle RF, et 
al. The Urokinase Plasminogen Activator (UPA) System in Uterine Natural Killer Cells in the Placental Bed During Early Pregnancy. Placenta. 2009; 30 (5): 398-404.

14. Pierleoni C, Castellucci M, Kaufmann P, Lund LR, Schnack Nielsen B, Urokinase receptor is up-regulated in endothelial cells and macrophages associated with fibrinoid deposits in the human placenta. Placenta. 2003; 24 (6): 677-85.

15. Breuss JM, Uhrin P. VEGF-initiated angiogenesis and the UPA uPAR system. Cell adhesion \& migration. 2012; 6 (6): 535-40.

16. Liu S, Zheng Q, Cui XY, Dai KX, Yang XS, Li FS, et al. Expression of UPAR in human trophoblast and its role in trophoblast invasion. Int J Clin Exp Pathol [Internet]. e-Century Publishing Corporation; 2015; 8 (11): 14325-34. Available from: https://www.ncbi.nlm. nih.gov/pmc/articles/PMC4713534/.

17. Xu Z, Meng L-L, Lin J, Ling Y, Chen S, Lin N. Association between the polymorphisms of urokinase plasminogen activation system and cancer risk: a meta-analysis. Onco Targets Ther [Internet] Dove Medical Press. 2015; 9 (8): 2493-502. Available from: http://www.ncbi.nlm.nih.gov/pmc/articles/PMC4574847/.

18. Andreasen P, Kjøller L, Christensen L, Duffy MJ. The urokinasetype plasminogen activator system in cancer metastasis: a review. Int J Cancer. 1997; 72 (1): 1-22.

19. Duffy MJ, Maguire TM, McDermott EW, O'Higgins N. Urokinase plasminogen activator: a prognostic marker in multiple types of cancer. J Surg Oncol. 1999; 71 (2): 130-5.

20. Fuhrman B. The urokinase system in the pathogenesis of atherosclerosis. Atherosclerosis. Ireland; 2012 May; 222 (1): 8-14.

21. Diamandis M, Paterson AD, Rommens JM, Veljkovic DK, Blavignac J, Bulman DE, et al. Quebec platelet disorder is linked to the urokinase plasminogen activator gene (PLAU) and increases expression of the linked allele in megakaryocytes. Blood. 2009; $113(7): 1543-6$. 